\title{
Anemia related to infection with Helicobacter pylori and intestinal parasites in the investigated subjects in Egypt
}

\author{
Fayez Muhammad Shaldoum \\ Department of Zoology, Faculty of Science, Al-Azhar University, \\ Madinat Nasr, Cairo, Egypt \\ fshaldoum@gmail.com
}

\begin{abstract}
Helicobacter pylori (H. pylori) are Gram-negative bacteria that colonize human gastric mucosa, leading to chronic gastritis. Parasitic infections are associated with $H$. pylori infection. This work aims is to evaluate the association of $H$. pylori and/or intestinal parasites infection with anemia in Egypt. Blood and stool specimens of 32 Subjects: 17 males and 15 females, whose age ranged from 1.5-65 years were analyzed for $H$. pylori antigen using Rapid Anti $H$. pylori test. Stool specimens were also examined microscopically for the presence of parasite eggs or larvae/cysts per wet amount by the saline concentration method. Complete blood counts (CBC) were calculated using Blood Cell Counter.

The results indicated that out of the collected 32 samples $17(53.1 \%)$ were males and $15(46.9 \%)$ were females; $22(68.8 \%)$ were infected (11 with H. pylori only (G1) and 11 with H. pylori and/or intestinal parasites (G2), 34.4\% each) and $10(31.2 \%)$ were not infected (control group). In the parasitic infected G2: 7 (63.6\%) were infected with protozoa and 3 $(27.3 \%)$ were infected with helminthes and $1(9.1 \%)$ has mixed infection with both protozoa and helminthes. Highly significant changes $(p<0.05)$ were observed for Hemoglobin level, RBCs count, Hct, Mean Cell Volume (MCV) and Mean Cell Hemoglobin (MCH) that were measured in $\mathrm{G} 1$ and $\mathrm{G} 2$ than in the control.

In conclusion, there are high prevalence of $H$. pylori and intestinal parasites infections and this was highly associated with anemia disease in the studied subjects.
\end{abstract}

Key words: Anemia, infection, Helicobacter pylori, Intestinal parasites, Egypt

\section{INTRODUCTIN}

The World Health Organization ${ }^{(\mathbf{1})}$ estimated that about two billion people in the world or almost a quarter of the world's population is anemic and suffering from this disease. Anemia is a widespread health problem and has social and economic development impacts. Anemia is defined as a decrease in the amount of red blood cells (RBCs) or the amount of hemoglobin $(\mathrm{Hb})^{(2)}$. Globally, more than 115000 maternal deaths and 591000 perinatal deaths per year are attributable to anemia ${ }^{(3)}$. It is estimated that $42 \%$ of pregnant women and $47 \%$ of preschool children are anemic ${ }^{(2)}$.

Helicobacter pylori infection is a worldwide problem but its prevalence varies from country to country ${ }^{(\mathbf{4})}$. Francesco et al. ${ }^{(\mathbf{5})}$ mentioned that some developing countries have figures as high as $90 \%$, whereas developed countries have values ranging from 25 to $40 \%$. $\mathrm{H}$. pylori is a Gram-negative bacterium that colonizes human gastric mucosa, leading to chronic antral gastritis and peptic ulcer disease. It is also associated with serious diseases, including gastric cancer and gastric mucosa associated lymphoid tissue lymphoma ${ }^{(\mathbf{6})}$. H. pylori infection not only present with recurrent abdominal pain, anorexia and recurrent vomiting, but also negatively affects the growth of children in various modalities; weight, height and the progressive incidence of iron deficiency anemia ${ }^{(7)}$.

Iron deficiency anemia (IDA) results in impairments in immune, cognitive, and reproductive functions, as well as decreased work performance although the mechanisms 
remain unclear ${ }^{(\mathbf{8})}$. The association between $H$. pylori infection and IDA has attracted considerable interests ${ }^{(\mathbf{9})}$.

Previous studies have shown that $H$. pylori colonization of the gastric mucosa may impair iron uptake and increase iron loss, potentially leading to iron deficiency anemia ${ }^{(\mathbf{1 0})}$. It has been suggested that eradication of $H$. pylori may result in improvement of anemia even without iron supplementation ${ }^{(11)}$. Uptake of iron by the $H$. pylori organism may contribute to iron deficiency associated with $H$. pylori infection like many bacteria ${ }^{(\mathbf{1 2})}$.

Intestinal parasites are among the most common human infections distributed worldwide with prevalence rates as high as $40.6 \%$ in developing countries,cause a variety of clinical conditions, ranging from asymptomatic infestations to life threatening situations ${ }^{(\mathbf{1 3})}$. Giardia lamblia can cause vomiting and diarrhea, the hookworms Ancylostoma duodenale and Necator americanus can cause blood loss and anemia, and Entamoeba histolytica can cause intestinal ulceration, bloody diarrhea, and systemic complications ${ }^{(\mathbf{1 4})}$. Because of their relationship with disease, intestinal parasites have been extensively eradicated in industrialized human societies, in which $H$. pylori also is disappearing ${ }^{(\mathbf{1 5})}$.

Huong et al. ${ }^{(\mathbf{1 6})}$ hypothesized that besides iron deficiency, intestinal parasites infection is also a determinant of anemia in school children in rural Vietnam. Blood loss caused by gastrointestinal parasites, such as hookworm, is an important contributing factor in the development of poor iron status leading to iron deficiency anemia ${ }^{(\mathbf{1 7})}$.Children with concomitant Trichuris trichiura and hookworm infections have lower blood hemoglobin levels than children with neither or only one of these parasites ${ }^{\mathbf{( 1 8})}$.Intestinal parasitic worms and $H$. pylori have detrimental effects on the survival, growth, general fitness and performance of children according to reports by Kosunen et al. ${ }^{(\mathbf{1 9})}$.

\section{Subjects:}

\section{SUBJECTS AND METHODS}

After taking consent from all 32 subjects, blood and stool specimens of: 17 males and 15 females, whose age ranged from 1.5-65 years were analyzed for $H$. pylori antigen using Rapid Anti $H$. pylori test. Stool specimens were also examined microscopically for the presence of parasite eggs or larvae/cysts per wet amount by the saline concentration method. Complete blood counts (CBC) were calculated using Blood Cell Counter.

\section{Stool Antigen Test for $H$. pylori:}

Stool test was performed in the immuneparasitology laboratory, Department of Zoology, Central laboratories, Faculty of Science, Al-Azhar University, Cairo, Egypt, using One Step H. pylori Card test ${ }^{(\mathbf{2 0})}$. Collected stool samples were transferred to vials with the extraction fluid, vigorously agitated, and left for two minutes for settling of suspended particulates. Two drops were then transferred into the circular port hole of the test cassette and results were recorded after $10 \mathrm{~min}$ of incubation at room temperature. Two red lines at the middle of the strip indicate a positive result, while negative result is an indication of only one red line.

\section{Parasitological methods:}

Stool samples were collected from patients in wide mouthed, screw capped, labeled containers, as described by Chakarova ${ }^{(\mathbf{2 1})}$. Samples were transported to Immunoparasitology Laboratory, Department of Zoology, Central laboratories, Faculty of Science, Al-Azhar University. Primary detection of cysts and ova were made by the examination of a wet preparation taken from fresh stool using light microscope (Achromatic biological microscope 107, China). 


\section{Anemia related to infection with Helicobacter pylori and intestinal parasites in the investigated subjects in Egypt}

\section{Collection of blood sample:}

The skin was cleaned with a $70 \%$ alcohol swab and allowed to dry before being punctured. Blood samples were taken by sterile venipuncture: $2.5 \mathrm{ml}$ of blood was drawn from the antecubital vein. $2.5 \mathrm{ml}$ in Ethylene Diamine Tetra Acetic acid (EDTA) tube for Complete Blood Count.

\section{Complete Blood Count (CBC):}

It was estimated using automated hematology Beckman Coulter Counter, USA. Grading of anemia was diagnosed as per WHO recommendations. Anemia was defined as hemoglobin of less than $11 \mathrm{mg} / \mathrm{l}$ for children under 6 years old, less than $12 \mathrm{mg} / \mathrm{l}$ for female and less than $13 \mathrm{mg} / \mathrm{l}$ for male, according to the WHO definition of anemia (DeMaeyer) ${ }^{(22)}$.

Analysis and interpretation data were entered and analyzed using (Minitab (® 18) Continuous variables were summarized using (means \pm SD) and categorical variables were summarized in frequencies (percentages). The difference in the mean values of RBC parameters between $H$. pylori positive and negative individuals was explored using independent sample T-test. In all cases P-values less than 0.05 were considered as statistically significant.

\section{RESULTS}

Level of Hemoglobin in the studied 32 subjects is shown in Table (1). The total percentage of Anemia was $62.5 \%$. There were 22 infected patients, $81.8 \%$ of them were anemic. Out of these infected patients, 11 were only $H$. pylori positive (G1) with $72 \%$ of them were anemic. The other 11 infected patients had both $H$. pylori and/or parasitic infections (G2) where $90.9 \%$ of them were anemic. The control group included 10 subjects and only $20 \%$ of them were anemic.

The male subjects were 17 (53.1\% of total studied subjects), of them 5 (22.7\% of all infected subjects) followed G1 and their mean level of hemoglobin was 12.2 \pm 0.60 ; the other 6 (27.3\% of all infected subjects) followed G2 and their hemoglobin level was $11.6 \pm 0.25$ and the other 6 ( $60 \%$ of control) had $14 \pm 0.27$ of hemoglobin level (Table 1, Figs. $1 \& 2)$. The female subjects were 15 (46.9\% of all infected subjects), of them $6(27.3 \%$ of all infected subjects) followed G1 and their mean level of hemoglobin was $10.8 \pm 0.51$; other $5(22.7 \%$ of all infected subjects) followed G2 and their hemoglobin level was $10.2 \pm 0.43$ and the other 4 ( $40 \%$ of control) had $12.2 \pm 0.40$ of hemoglobin level (Table 1, Figs, 1 \& 2).

All studied subjects were divided into 3 age groups: 12 (37.5\%) young, $16(50 \%)$ middle and $4(12.5 \%)$ old age. In the young age group: 3 (13.6\% of all infected subjects) followed G1 and their mean level of hemoglobin was $11 \pm 1.0$; other 5 (22.7\% of all infected subjects) followed G2 and their hemoglobin level was $10.4 \pm 0.43$ and the other 4 (40\% of control) had $12.98 \pm 0.39$ of hemoglobin level (Table 1, Figs. $1 \& 2$ ). In the middle age group: $6(27.3 \%$ of all infected subjects) followed G1 and their mean level of hemoglobin was $11.45 \pm 0.62$; other 5 (22.7\% of all infected subjects) followed G2 and their hemoglobin level was $11.5 \pm 0.47$ and the other 5 (50\% of control) had $13.7 \pm 0.86$ of hemoglobin level (table 1 ; figures 1 and 2). In the old age group: 2 (9.1\% of all infected subjects) followed G1 and their mean level of hemoglobin was $12.1 \pm 0.65$; another one (4.5\% of all infected subjects) followed G2 and his hemoglobin level was 11.5 and the other one (10\% of control) had 12.7 of hemoglobin level (Table 1, Figs. $1 \& 2$ ).

Complete blood counts of all subjects infected (G1 and G2) and the non-infected control were studied (Table 2, Fig. 3). There was significant association of lower Hemoglobin level $(\mathrm{Hb})$ in $\mathrm{G} 1$ and $\mathrm{G} 2$ than the control where association of lower Red Blood Cell Counts (RBCs) was only significant with G1 than control group (Table 2, Fig. 3A). 


\section{Blood indices:}

There were significant association of lower Hematocrit (Hct), Mean Cell Volume $(\mathrm{MCV})$ and Mean Cell Hemoglobin $(\mathrm{MCH})$ in $\mathrm{G} 1$ and $\mathrm{G} 2$ than the controls (Table 2, Fig. 3B). There was no significant association of Mean Cell Hemoglobin Concentration (MCHC) with G1 or G2. There was no significant association of Platelets (Plt) with G1 or G2 (Table 2. Fig. 3C).

\section{Differential leucocytes count:}

There were no significant association of leucocytes count with either G1 or G2 Except for significant eosinophilia associated to G2 compared to control group (Table 2, Fig. 3D).

\section{DISCUSSION}

The prevalence of $H$. pylori infection in the current study was $68.8 \%$ as the high rates previously reported in India by Escobar-Pardo et $a ._{.}^{(\mathbf{2 3})}$ and in Pakistan by Rasheed et al. ${ }^{(\mathbf{2 4})}$. While, Alazmi et al. ${ }^{(25)}$ (in Kuwait), Obiageli and Ivan ${ }^{(\mathbf{2 6})}$ (in Nigeria) and Taddesse et al. ${ }^{(27)}$ (in Ethiopia) have found lower prevalence of $H$. pylori infection than in the present study.

The results of the current study also showed no significant association between infection with either $H$. pylorior intestinal parasites and Sex. Several studies and reports agree with these findings: Adlekha $e$ al. $^{(\mathbf{2 8 )}}$ (in India); Ahmed et al. ${ }^{(\mathbf{2 0 )}}$ (in Pakistan); Obiageli and Ivan $^{(26)}$, (in Nigeria); Shokrzadeh et al. ${ }^{(29)}$ (in Iran) have found no difference between males and females regarding H. Pylori infection, Hamed et al. ${ }^{(\mathbf{3 0 )}}$ in Sohag, Egypt); Mezeid et al. ${ }^{(31)}$ (in Palestine); Obiageli and $\operatorname{Ivan}^{(\mathbf{2 6})}$ (in Nigeria). While, Leandro et al. ${ }^{(\mathbf{3 2})}$ (in Spain) reported a significant association between $H$. pylori infection and male gender (without explanation). However, other studies by: Lee et al. ${ }^{(33)}$ (in Korea) and Shehata and Hassanein ${ }^{(34)}$ (in Alexandria) showed noticeable higher infection rate with intestinal parasites in males than in females. Opposite to these data, Bin Mohanna et al. ${ }^{(35)}$ (Yemen) found that the prevalence of $H$. pylori and intestinal parasites in females was higher than in males. So the infection may relate to the daily activity of the patients and with socioeconomic conditions, rather than sex. The current study showed that gender is not associated with Anemia in case of infection with H. pylori and/or intestinal parasites.

Anemia affects 2 billion people in the world (WHO) ${ }^{(36)}$. Many areas of the world that are with high prevalence of iron-deficiency have also high $H$. pylori prevalence as well. The current study showed that the co-infection of $H$. pylori and/or intestinal parasites was associated with anemia within the investigated patients. The prevalence of anemia among infected patients was significantly higher $(81.8 \%)$ than uninfected patients $(20 \%)$. Many studies support the role of $H$. pylori in the development of refractory iron - deficiency anemia $^{(37)}$. However, other studies documented no statistically significant association of $H$. pylori infection with anemia or low iron status ${ }^{(38)}$.

The virulence of $H$. pylori microorganisms scavenges iron and/or haem compounds from their host environment for its survival in the host and thus production of disease ${ }^{(39)}$. Chronic infection and inflammatory cytokines of the $H$. pylori organism altered iron bioavailability and decreased non-heme iron absorption caused by hypochlorhydria ${ }^{(40)}$.

The present study found that $H$. pylori positive patients have significantly reduced hemoglobin, Red blood cell count (RBCs), Mean Cellular Volume (MCV), Mean Cellular hemoglobin $(\mathrm{MCH})$ and hematocrit levels than H. pylori negative patients. Some other data agree with the present findings ${ }^{(\mathbf{4 1 )}}$ but others disagree ${ }^{(\mathbf{4 2})}$. Interestingly, sideropenic anemia is not associated with hematemesis or tarry stools, suggesting that long-standing $H$. pylori 


\section{Anemia related to infection with Helicobacter pylori and intestinal parasites in the investigated subjects in Egypt}

infection itself can cause anemia in the absence of active bleeding from the gastrointestinal tract $^{(43)}$.

The infection rate, in this study, was high (50\%) in middle age group for $\mathrm{H}$. pylori. These data agree with the findings of Kaore et al. ${ }^{(\mathbf{4 4})}$ (in India) and Shokrzadeth et al. ${ }^{(\mathbf{2 9})}$ (in Iran) where they have found that $H$. pylori positivity increased with age of (20-40) years. However, the current data disagree with Escobar-Pardo et $a{ }^{(\mathbf{( 2 3 )}}$ (in India) who found that the infection rate of $H$. Pylori was high and affecting $60 \%$ of children in the first 3 years of life and rising to $85.3 \%$ between 8 and 9 years of age. Also, Obiageli and Ivan ${ }^{(26)}$ (in Nigeria) have detected the highest $(56.2 \%)$ prevalence of $H$. pylori within the age group (3847) years, while the age (18-27) years had the least (39.7\%) bacterial infection. This indicates that the prevalence curve of acquisition of $H$. pylori infections rises with age, which may be due to outdoor activities and exposure to potential external sources.

The infection rate with intestinal parasites, however, was high $(45.5 \%)$ in young group, in the current study. Other studies have also shown high prevalence of intestinal parasitic infection among young ${ }^{(\mathbf{3 4}, \mathbf{4 5})}$. The current study found that anemia was prevalent within the young age group. These data agree with several studies that have shown prevalence of $H$. pylori infection in childhood is associated with growing faltering ${ }^{(46)}$.

In the present study protozoa, is more associated with $H$. pylori in subjects infected with anemia than helminthes.These observations disagree with study suggesting that $H$. pylori infection next to helminthiasis is a communicable cause of anemia ${ }^{(47)}$. Other studies reported also a significant association of intestinal parasites such as, Ascaris ${ }^{(\mathbf{4 8})}$ and hookworm $^{(49)}$, with anemia.

Several mechanisms of association between anemia and $H$. pylori infection have been suggested. Studies have shown that the $H$. pylori colonization is associated with reduction in iron absorption due to low levels of gastric acid ${ }^{(\mathbf{5 0})}$, effects on iron transporter molecules ${ }^{(\mathbf{5 1})}$, blood loss due to $H$. pylori-induced gastritis or duodenitis and sequestration of dietary iron by $H$. pylori residing in the gastric mucosa ${ }^{(47)}$. Increased hepcidin production from hepatocytes in response to interleukin-6 (IL-6) production in H. pylori gastritis has also been proposed as possible mechanism to explain $H$. pylori associated anemia ${ }^{(\mathbf{5 2})}$, as this prevents the release of iron from stores in enterocytes.

\section{Conclusions}

There are high prevalence of $H$. pylori and intestinal parasites infections in the investigated subjects in Egypt. These infections were highly associated with anemia disease in the studied subjects. Although gender is not a significant factor neither associated with infection nor with anemia, middle age is associated with both infection and anemia.

\section{R REFERENCES}

1-World Health Organization (2005). Deworming for health and development Report of the third global meeting of the partners for parasite control, Geneva Switzerland: World Health Organization.

2-World Health Organization (2008). Worldwide Prevalence of Anemia 1993-2005: WHO Global Database on Anemia, World Health Organization, Geneva, Switzerland.

3- Ezzati, Majid, Lopez, Alan D, Rodgers, Anthony A \& Murray, Christopher J. L. (2004). Comparative quantification of health risks : global and regional burden of disease attributable to selected major risk factors / edited by Majid Ezzati ... [et al.]. Geneva : World Health Organization. http://www.who.int/iris/handle/10665/42770 
4-Suerbaum, S. and Michetti, P. (2002). Helicobacter pylori infection. N. Engl. J. Med., 347:1175-1186.

5-Francesco, F.; Tortora, A.; Di, R.T.; D’Angelo, G. and Gianluca, I. (2014). Role of Helicobacter pylori infection on nutrition and metabolism World J. Gastroenterol., 20: 12809-12817

6-Sethi, A.; Chaudhuri. M.; Kelly, L. and Hopman, W. (2013). Prevalence of Helicobacter pylori in a frst nations population in Northwestern Ontario. Canad. Family Physician, 59(4):e182-e187

7-Razak, A. and Ragab, M.S. (2014). Helicobacter pylori Infections in Children of a Rural Community. J. Bacteriol. Parasitol., 5:1-4

8-Blaser, M.J. and Atherton, J.C. (2004). Helicobacter pylori persistence: biology and disease. J. Clin. Invest., 113:321-333.

9- Varbanova M; Frauensclager K and Malfertheiner P (2014): Chronic gastritis- an update. Best Pract Res Clin Gastroenterol., 28: 1031-1042

10-Monzon, H.; Forn, M. and Esteve, M. (2013). Helicobacter pylori infection as a cause of iron deficiency anaemia of unknown origin. World J. Gastroenterol., 19: 4166-4171.

11-Malik, R.; Guleria, K.; Kaur, I.; Sikka, M. and Radhakrishnan, G. (2011). Effect of Helicobacter pylori eradication therapy in iron deficiency anaemia of pregnancy - A pilot study. Ind. J. Med. Res., 134:224-231.

12-Seo, J.K.; Ko, J.S. and Choi, K.D. (2002). Serum ferritin and Helicobacter pylori infection in children: a sero-epidemiologic study in Korea. J. Gastroenterol. Hepatol., 17:754-757

13-Sethi, S.; Sehgal, R.; Malla, N.; Dubey, M.L. and Mahajan, R.C. (2000). Changing trends of parasitic infections in Chandigarh (Northern India): hospital based study. Ind. J. Med. Microbiol., 18:106-9.

14-Kucik, C.J.; Martin, G.L. and Sortor, B.V. (2004). Common intestinal parasites. Am. Family Physician, 69: 1161-1168

15-Perez-Perez, G.I.; Salomaa, A.; Kosunen, T.U.; Daverman, B.; Rautelin, H.; Aromaa, A.; Knekt, P. and Blaser, J. (2002). Evidence that cagA(+) Helicobacter pylori strains are disappearing more rapidly than cagA(-) strains. Gut, 50: 295-298.

16-Huong, T.; Le, H.T.; Brouwer, I.D.; Verhoef, H.; Nguyen, Kh.C. and Kok, F.J. (2007). Anemia and intestinal parasite infection in school children in rural Vietnam. Asia. Pac. J. Clin. Nutr., 16:716-723

17-Robertson, L.J.; Crompton, D.W.; Sanjur, D. and Nesheim, M.C. (1992). Hemoglobin concentrations and concomitant infections of hookworm and Trichuris trichiura in Panamanian primary school children. Transactions of the Royal Society of Tropical Medicine and Hygiene, 86:654-656

18-Crompton, D.W.T. (2000). The public health importance of hookworm disease. Parasitology; 12: S39-S50

19-Kosunen, T.U.; Aromaa, A. and Knekt, P. (1997). Helicobacter Antibodies in 1973 and 1994 in the Adult Population of Vammala, Finland. Epidemiology \& Infection, 119: 2934. Avilable at: http://dx.doi.org/10.1017/S0950268897007565

20-Ahmed, N.F.M.; Elfaki, T.E.M. and Elsayid, M. (2016). Prevalence Rate of Giardia Lamblia/Helicobacter Pylori Co-Infections in Khartoum State, Sudan. Int. J. Scintific \& Technol. Res., 5: 2277-8616.

21-Chakarova, B. (2010). Comparative evaluation of the diagnostic methods for detection of Giardia intestinalis in human fecal samples. Trakia J. Sci., 8: 174-179.

22-DeMaeyer, E. and Adiels-Tegman, M. (1985). The prevalence of anemia in the world. World Health Statistics Quarterly, 38:302-316 


\section{Anemia related to infection with Helicobacter pylori and intestinal parasites in the investigated subjects in Egypt}

23-Escobar-Pardo, M.L.; de Godoy, A.P.O.; Machado, R.S.; Rodrigues, D.; Neto, U.F. and Kawakami, E. (2011). Prevalence of Helicobacter pylori infection and intestinal parasitosis in children of the Xingu Indian Reservation. J. Pediatria, 11:87-05

24-Rasheed, F.; Ahmad, T. and Bilal, R. (2011). Frequency of Helicobacter pylori infection using 13C-UBT in asymptomatic individuals of Barakaho, Islamabad, Pakistan. J. Coll. Physicians Surg. Pak., 21: 379-381.

25-Alazmi, W.M.; Siddique, I.; Alateeqi, N. and Al-Nakib, B. (2010). Prevalence of Helicobacter pylori infection among new outpatients with dyspepsia in Kuwait. BMC Gastroenterol., 10:1-4

26-Obiageli, E.R. and Ivan, E.C. (2016). Prevalence of Helicobacter Pylori and its associated peptic ulcer infection among adult residents of Aba, Southeastern, Nigeria. Int. J.Current Microbiol. Appl. Sci., 6: 16-21.

27-Taddesse, G.; Habteselassie, A.; Desta, K.; Esayas, S. and Bane, A. (2011). Association of dyspepsia symptoms and Helicobacter pylori infections in private higher clinic, Addis Ababa, Ethiopia. Ethiop. Med. J., 49:109-116.

28-Adlekha, S.; Chadha, T.; Krishnan, P. and Sumangala, B. (2013). Prevalence of Helicobacter pylori infection among patients undergoing upper gastrointestinal endoscopy in a medical college hospital in Kerala, India. Annals of Med. Health Sci. Res., 4: 559-563.

29-Shokrzadeh, L.; Baghaei, K.; Yamaoka, Y.; Shiota, S.; Mirsattari, D.; Porhoseingholi, A. and Zali, M.R. (2012). Prevalence of Helicobacter pylori infection in dyspeptic patientsin. Iran. Gastroenterol. Insights, 4: 24-27.

30- Hamed M E; Hussein H M; El Sadany H F; Elgobashy A A and Atta A H (2013). Seroprevalence of Helicobacter pylori infection among family members of infected and non-infected symptomatic children. J Egypt Soc Parasitol., 43: 755-66

31- Mezeid N; Shaldoum F; Al-Hindi A; Mohamed F S A and Darwish Z E A (2014): Prevalence of intestinal parasites among the population of the Gaza Strip, Palestine. Annals of Parasitology, 4: 281-289

32-Leandro, L.S.V.; Hernandez, G.M.; Torroba, A.L.; Sanchez, M.F.; Leandro, C.S.E.; Gomez, A.A. and Chueca, R.P. (2005). Helicobacter pylori infection in the child population in Spain: prevalence, related factors and influence on growth. An Pediatr (Barc). 63:489-494.

33-Lee, J.; Park, G.M.; Lee, D.H.; Park, S.J. and Yong, T.S. (2000). Intestinal parasite infections at an institution for the handicapped in Korea. Korean J. Parasitol., 38: 179181.

34-Shehata, A.I. and Hassanein, F. (2015). Intestinal parasitic infections among mentally handicapped individuals in Alexandria, Egypt. Annals Parasitol., 61:275-281.

35-Bin Mohanna, M.A.; Al-zubairi, L.M. and Sallam, A.K. (2014). Prevalence of Helicobacter pylori and parasites in symptomatic children examined for antibodies, antigens, and parasites in Yemen. Saudi Med. J., 35: 1408-1411.

36-World Health Organization (2004). The United Nations Children's Fund, United Nations University. Iron deficiency anaemia: assessment, prevention, and control. Available at: http://www.who.int/ nut/documents/_assessment_prevention_control.pdf, accessed 27 July,

37-Kibru, D.; Gelaw, B.; Alemu, A. and Addis, Z. (2014). Helicobacter pylori infection and its association with anemia among adult dyspeptic patients attending Butajira Hospital, Ethiopia. BMC Infectious Diseases, 14: 1471-1477 
38-Hsiang-Yao, S.; Fu-Chen, K. and Sophie, S. (2013). Helicobacter pylori infection and anemia in Taiwanese adults. Gastroenterology Research and Practice, Article ID390967, 4 pages.

39-Sabbi, T.; De Angelis, P.; Colistro, F.; Dall'Oglio, L. and di Abriola, G.F. (2005). Efficacy of noninvasive tests in the diagnosis of Helicobacter pylori infection in pediatric patients. Arch Pediatr. Adolesc. Med., 159: 238-241.

40-Poulo, T.M. (2008). Helicobacter pylori infection, overview with Medicine Pediatr: General Medicine.

41-Taye, B.; Enquselassie, F.; Tsegaye, A.; Amberbir, A.; Medhin, G.; Fogarty, A.; Robinson, K. and Davey, G. (2015). Effect of early and current Helicobacter pylori infection on the risk of anaemia in 6.5-year-old Ethiopian children. BMC Infectious Diseases, 15:270- 282

42-Fraser, A.G.; Scragg, R.; Schaaf, D.; Metcalf, P. and Grant, C.C. (2010). Helicobacter pylori infection and iron deficiency in teenage females in New Zealand. N.Z. Med. J., 123:38-45.

43-Kato, S.; Nishino, Y.; Ozawa, K.; Konno, M. and Maisawa, S. (2004). The prevalence of Helicobacter pylori in Japanese children with gastritis or peptic ulcer disease. J Gastroenterol., 39: 734-738.

44-Kaore, N.M.; Nagdeo, N.V. and Thombare, V.R. (2012). Comparative evaluation of the diagnostic tests for Helicobacter pylori and dietary influence for its acquisition in dyspeptic patients: A rural hospital based study in central India. JCDR.,6: 636-641.

45-Tappeh, K.H.; Mohammadzadeh, H.; Rahim, R.N.; Barazesh, A.; Khashaveh, S. and Taherkhani, H. (2010). Prevalence of intestinal parasitic infections among mentally disabled children and adults of Urmia, Iran. Iran. J. Parasitol.,5: 60-64.

46-Vinod, K.C.S.; Anand, K.H.; Sunita, V. and Kapur, I. (2003). Prevalence of anemia and worm infestation in school going girls at Gulbarga, Karnataka [letter]. Indian Pediatrics, 40:70-72

47-Barabino, A. (2002). Helicobacter pylori-related iron defciency anemia: a review. Helicobacter, 7:71-75.

48-Wani, S.A.; Ahmad, F.; Zargar, S.A.; Dar, Z.A.; Dar, P.A.; Tak, H. and Fomda, B.A. (2008). Soil-transmitted helminths in relation to hemoglobin status among school children of the Kashmir Valley. J. Parasitol., 94: 591-593

49-Calis, J.C.; Phiri, K.S.; Faragher, E.B.; Brabin, B.J.; Bates, I.; Cuevas, L.E.; de Haan, R.J.; Phiri, A.I.; Malange, P.; Khoka, M.; Hulshof, P.J.; van Lieshout, L.; Beld, M.G.; Teo, Y.Y.; Rockett, K. A.; Richardson, A.; Kwiatkowski, D.P.; Molyneux, M.E. and van Hensbroek, M.B. (2008). Severe anemia in Malawian children. N. Engl. J. Med.,358: 888-899

50-Capurso, G.; Lahner, E.; Marcheggiano, A.; Caruana, P.; Carnuccio, A. and Bordi, C. (2001). Involvement of the corporal mucosa and related changes in gastric acid secretion characterize patients with iron deficiency anaemia associated with Helicobacter pylori infection. Aliment Pharmacol.Ther.,15:1753-61.

51-Choe, Y.H.; Oh, Y.J.; Lee, N.G.; Imoto, I.; Adachi, Y. and Toyoda, N. (2003). Lactoferrin sequestration and its contribution to iron-deficiency anemia in Helicobacter pylori infected gastric mucosa. J. Gastroenterol. Hepatol., 18(8):980-5.

52-Pellicano, R. and Rizzetto, M. (2004). Is hepcidin the bridge linking Helicobacter pylori and anemia of chronic infection? A research proposal. Panminerva Med., 46:165-9. 
Anemia related to infection with Helicobacter pylori and intestinal parasites in the investigated subjects in Egypt

Table 1: Level of Hemoglobin ( $\mathrm{Hb} \mathrm{g} / \mathrm{dl})$ in the studied infected and control subjects 32 (Anemia: 62.5\%).

\begin{tabular}{|c|c|c|c|c|c|c|}
\hline \multirow{3}{*}{$\begin{array}{c}\text { VariableN } \\
(\%)\end{array}$} & \multicolumn{4}{|c|}{$\begin{array}{c}\text { Infected } \\
22(\text { Anemia: } 81.8 \%) \\
\end{array}$} & \multirow{2}{*}{\multicolumn{2}{|c|}{$\begin{array}{c}\text { Control } \\
10 \text { (Anemia: 20\%) }\end{array}$}} \\
\hline & \multicolumn{2}{|c|}{$\begin{array}{c}\text { H. pylori } \\
11 \text { (Anemia: } 72 \%)\end{array}$} & \multicolumn{2}{|c|}{$\begin{array}{c}\text { Parasites\&H. pylori } \\
11 \text { (Anemia: } 90.9 \% \text { ) }\end{array}$} & & \\
\hline & $\mathbf{N}(\%)$ & $\begin{array}{c}\text { Hb }(\mathrm{g} / \mathrm{dl}) \\
\text { Mean } \pm \text { S. E }\end{array}$ & $\mathbf{N}(\%)$ & $\begin{array}{c}\mathbf{H b}(\mathrm{g} / \mathrm{dl}) \\
\text { Mean } \pm \text { S. E }\end{array}$ & $\mathbf{N}(\%)$ & $\begin{array}{c}\text { Hb }(\mathrm{g} / \mathrm{dl}) \\
\text { Mean } \pm \text { S. E }\end{array}$ \\
\hline $\begin{array}{c}\text { Male } \\
17(53.1)\end{array}$ & $5(22.7)$ & $12.2 \pm 0.60$ & $6(27.3)$ & $11.6 \pm 0.25$ & $6(60)$ & $14 \pm 0.27$ \\
\hline $\begin{array}{l}\text { Female } \\
15(46.9)\end{array}$ & $6(27.3)$ & $10.8 \pm 0.51$ & $5(22.7)$ & $10.2 \pm 0.43$ & $4(40)$ & $12.2 \pm 0.40$ \\
\hline $\begin{array}{c}\text { Young12 } \\
(37.5)\end{array}$ & 3 (13.6) & $11 \pm 1.0$ & $5(22.7)$ & $10.4 \pm 0.43$ & $4(40)$ & $12.98 \pm 0.39$ \\
\hline $\begin{array}{l}\text { Middle } 16( \\
50)\end{array}$ & $6(27.3)$ & $11.45 \pm 0.62$ & $5(22.7)$ & $11.5 \pm 0.47$ & $5(50)$ & $13.7 \pm 0.86$ \\
\hline $\begin{array}{c}\text { Old } \\
4(12.5)\end{array}$ & $2(9.1)$ & $12.1 \pm 0.65$ & $1(4.5)$ & 11.5 & $1(10)$ & 12.7 \\
\hline
\end{tabular}

$\mathrm{P}=0.8$; standard levels for hemoglobin $(\mathrm{Hb})$ are: male $=13-18$, female $=12-16$ and young=11-15.

Table 2: Complete blood counts of subjects infected with $\boldsymbol{H}$. pylori and or intestinal parasites and without infection (control).

\begin{tabular}{|c|c|c|c|}
\hline Haematological findings & $\begin{array}{c}\text { H. Pylori (G1) } \\
\text { N=11 } \\
\text { Min- Max } \\
\text { Mean } \pm \text { SD }\end{array}$ & $\begin{array}{c}\text { H. Pylori \&intestinal } \\
\text { parasites }(\mathrm{G} 2)(\mathrm{N}=11) \\
\text { Min.- Max } \\
\text { Mean } \pm \text { SD }\end{array}$ & $\begin{array}{c}\text { Control } \\
\mathrm{N}=10\end{array}$ \\
\hline Hb (g/dl.) & $\begin{array}{l}9.5-13 * * \\
11.45 \pm 0.43\end{array}$ & $\begin{array}{l}9.8-12.5 * * * \\
11.3 \pm 1.1\end{array}$ & $\begin{array}{l}11.2-15.1 \\
13.3 \pm 0.37\end{array}$ \\
\hline $\operatorname{RBCs}\left(\mathrm{m} / \mathrm{mm}^{3}\right)$ & $\begin{array}{l}3.7-4.8 * \\
4.3 \pm 0.12\end{array}$ & $\begin{array}{l}3.9-5.0 \\
4.2 \pm 0.34\end{array}$ & $\begin{array}{l}3.9-5.2 \\
4.6 \pm 0.13\end{array}$ \\
\hline HCt $(\%)$ & $\begin{array}{l}29.1-39.3 * * \\
34.7 \pm 1.25\end{array}$ & $\begin{array}{l}30.2-41.1 * * * \\
34.4 \pm 3.38\end{array}$ & $\begin{array}{l}34-46 \\
40.2 \pm 1.14\end{array}$ \\
\hline $\operatorname{MCV}$ (fl) & $\begin{array}{l}72.4-86.0^{*} \\
79.5 \pm 1.37\end{array}$ & $\begin{array}{l}77-84 * \\
80.8 \pm 2.6\end{array}$ & $\begin{array}{l}82.9-92 \\
86.5 \pm 0.83\end{array}$ \\
\hline MCH (pg) & $\begin{array}{l}24.6-28 * * \\
26.2 \pm 0.37\end{array}$ & $\begin{array}{l}25.2-27.7 * * \\
26.5 \pm 0.72\end{array}$ & $\begin{array}{l}27-33 \\
29.0 \pm 0.50\end{array}$ \\
\hline $\operatorname{MCHC~(g/dl)~}$ & $\begin{array}{l}32.5-34 \\
32.97 \pm 0.13\end{array}$ & $\begin{array}{l}32-33 \\
32.6 \pm 0.48 \\
\end{array}$ & $\begin{array}{l}30.9-33.1 \\
32.6 \pm 0.20\end{array}$ \\
\hline $\begin{array}{l}\text { Platelets } \\
\text { (thousands/mm') }\end{array}$ & $\begin{array}{l}117-312 \\
229.6 \pm 12.96\end{array}$ & $\begin{array}{l}168-265 \\
214.5 \pm 39.7\end{array}$ & $\begin{array}{l}167-319 \\
244.2 \pm 16.72\end{array}$ \\
\hline WBCs & $\begin{array}{l}4.1-12.8 \\
7.6 \pm 0.80\end{array}$ & $\begin{array}{l}3.2-11 \\
7.3 \pm 0.8\end{array}$ & $\begin{array}{l}4.8-11 \\
7.6 \pm 0.64\end{array}$ \\
\hline Eosinophils & $\begin{array}{l}1.9-4 \\
2.9 \pm 0.21\end{array}$ & $\begin{array}{l}3.1-6 * * * \\
4.48 \pm 0.29\end{array}$ & $\begin{array}{l}1.7-4 \\
2.68 \pm 0.23\end{array}$ \\
\hline Neutrophils & $\begin{array}{l}47.9-62 \\
51.7 \pm 1.27\end{array}$ & $\begin{array}{l}35.5-68.2 \\
53.3 \pm 3.07\end{array}$ & $\begin{array}{l}49-63 \\
55.3 \pm 1.4\end{array}$ \\
\hline Lymphocytes & $\begin{array}{l}29-46 \\
39.75 \pm 1.37\end{array}$ & $\begin{array}{l}15.4-53.8 \\
37.7 \pm 3.17\end{array}$ & $\begin{array}{l}28-42 \\
35.7 \pm 1.5\end{array}$ \\
\hline Monocytes & $\begin{array}{l}2-8.5 \\
5.6 \pm 0.59\end{array}$ & $\begin{array}{l}2-9.9 \\
5.245 \pm 0.60\end{array}$ & $\begin{array}{l}3.9-7.3 \\
3.9-7.3\end{array}$ \\
\hline
\end{tabular}

$\mathrm{N}=$ Number of studied subjects 
Fayez M. Shaldoum

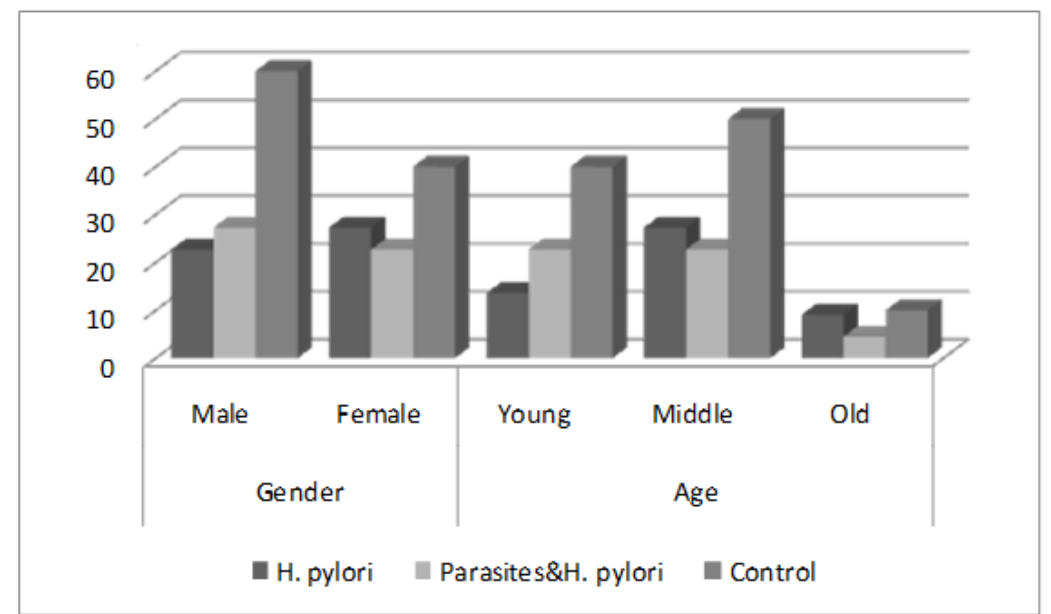

Fig. 1: Percentage number of the studied infected (H. pylori and/or parsite) and control subjects.

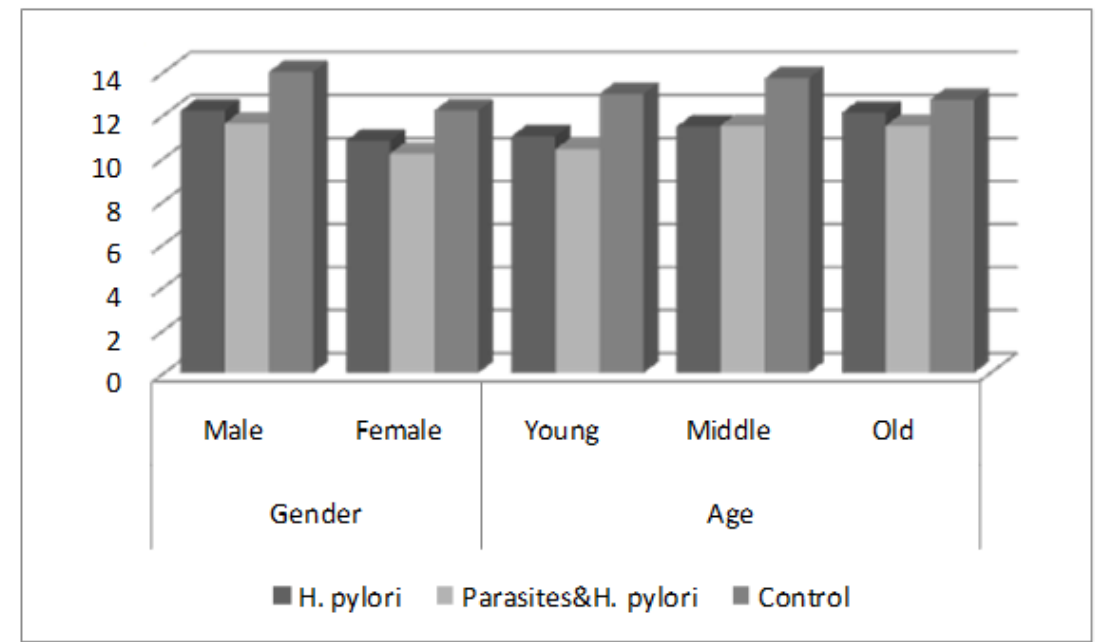

Fig. 2: Hemoglobin (Hb g/dl) in the studied infected (H. pylori and/or parsite) and control subjects. 
Anemia related to infection with Helicobacter pylori and intestinal parasites in the investigated subjects in Egypt

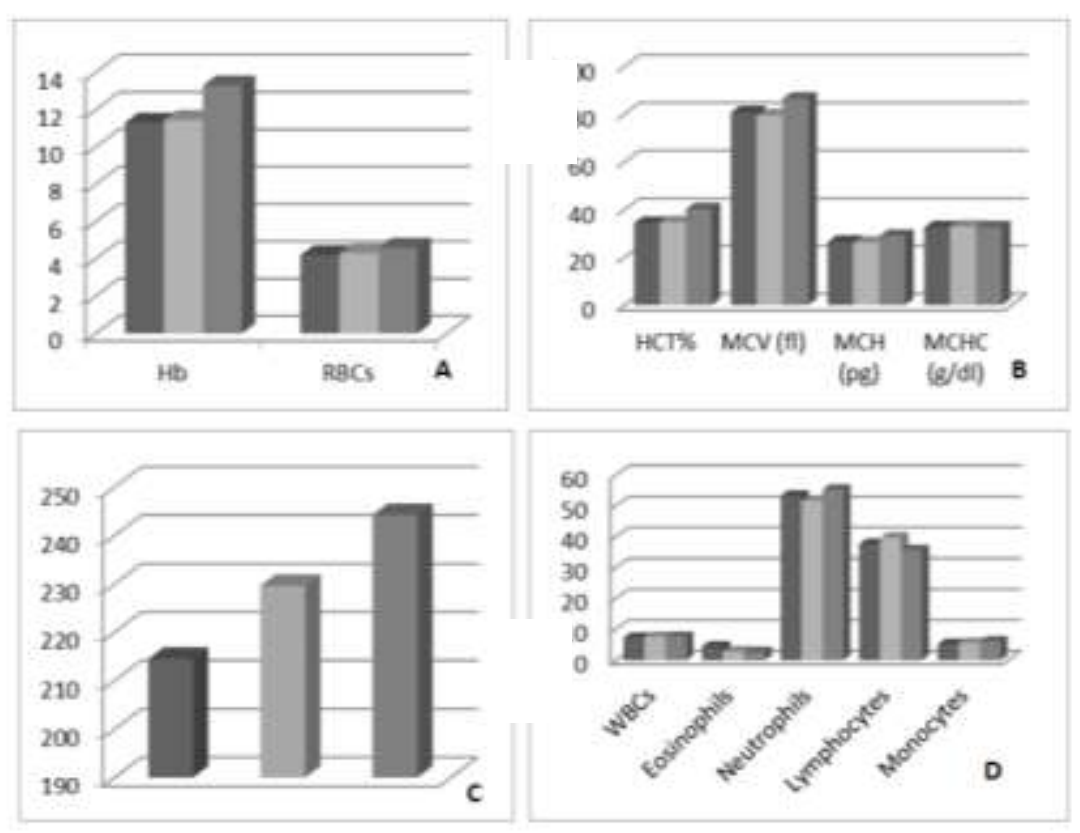

Fi.g. 3: Complete blood counts $(\mathrm{CBC})$ in the studied infected (H. pylori and/or parsite) and control subjects, A: hemoglobin (Hb g/dl) and red blood cells $\left(\mathrm{RBCs} \mathrm{m} / \mathrm{mm}^{3}\right.$; B: blood indices; C: Platelets; D: differential counts.

$\square$ H. pylori\& parasite; $\square$ H. pylori; $\square$ Control 


\title{
الأنيميا وعلاقتها بالإصابة بجرثومة المعدة والطفيليات المعوية فى الحالات التى تم فحصها بمصر
}

\author{
فايز محمد شلضوم \\ قسم علم الحيو ان، كلية العلوم للبنين، جامعة الأز هر ، القاهرة، مصر
}

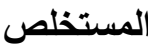

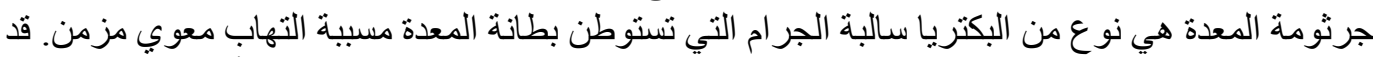

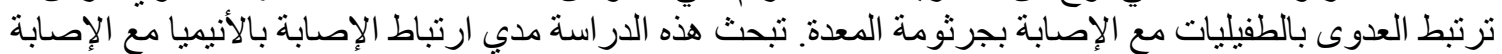

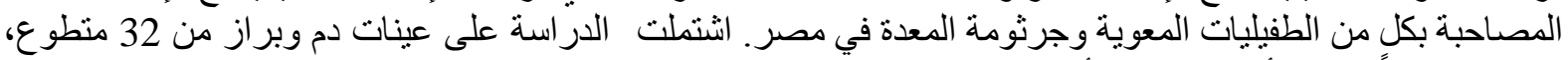

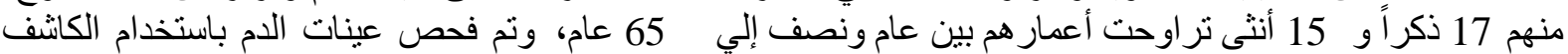

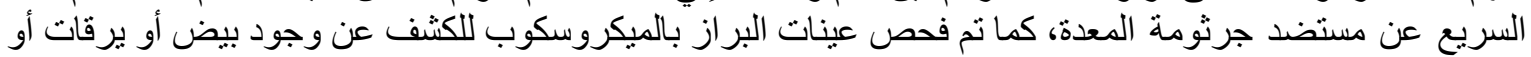

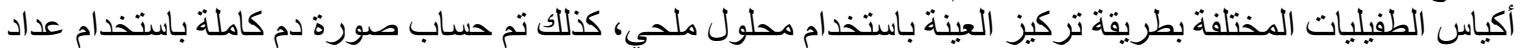
خلايا الام. أظهرت النتائج أن من بين 32 منطوع كان عدد الذكور 17 بنسبة 53.1\% و

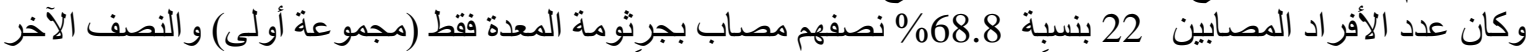

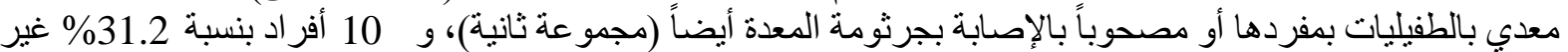

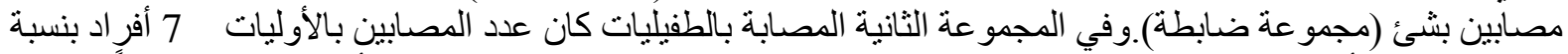

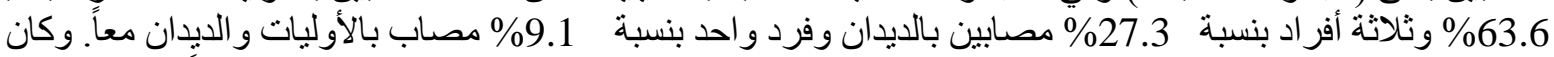

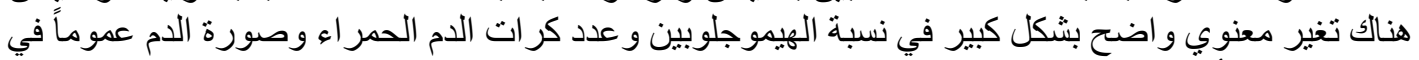

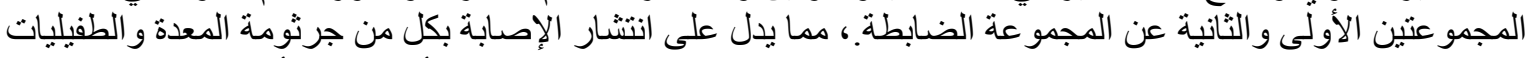
بين الافر اد المتطو عين فى هذه الدراسة من المصريين وارتباط هذه العدوى بمرض الألنيميا في الأفر اد المصابين. 